\title{
Thermo-Catalytic Methane Decomposition for Hydrogen Production: Effect of Palladium Promoter on Ni-based Catalysts
}

\author{
Irene Lock Sow Mei ${ }^{1}$, S.S.M. Lock ${ }^{1}$, Dai-Viet N. Vo², Bawadi Abdullah ${ }^{1,3^{*}}$ \\ ${ }^{1}$ Chemical Engineering Department, Universiti Teknologi PETRONAS, Bandar Sri Iskandar, \\ 32610, Perak, Malaysia \\ ${ }^{2}$ Faculty of Chemical \& Natural Resources Engineering, Universiti Malaysia Pahang, Lebuhraya \\ Tun Razak, 26300 Gambang, Kuantan, Pahang, Malaysia \\ ${ }^{3}$ Center of Biofuel and Biochemical Research (CBBR), Universiti Teknologi PETRONAS, 32610, \\ Bandar Seri Iskandar, Perak, Malaysia
}

Received: 21st January 2016; Revised: $6^{\text {th }}$ February 2016; Accepted: $6^{\text {th }}$ March 2016

\section{Abstract}

Hydrogen production from the direct thermo-catalytic decomposition of methane is a promising alternative for clean fuel production. However, thermal decomposition of methane can hardly be of any practical and empirical interest in the industry unless highly efficient and effective catalysts, in terms of both catalytic activity and operational lifetime have been developed. In this study, the effect of palladium (Pd) as a promoter onto $\mathrm{Ni}$ supported on alumina catalyst has been investigated by using coprecipitation technique. The introduction of $\mathrm{Pd}$ promotes better catalytic activity, operational lifetime and thermal stability of the catalyst. As expected, highest methane conversion was achieved at reaction temperature of $800{ }^{\circ} \mathrm{C}$ while the bimetallic catalyst ( 1 wt. $\% \mathrm{Ni}-1$ wt.\% $\mathrm{Pd} / \mathrm{Al}_{2} \mathrm{O}_{3}$ ) gave the highest methane conversion of $70 \%$ over 15 min of time-on-stream (TOS). Interestingly, the introduction of Pd as promoter onto Ni-based catalyst also has a positive effect on the operational lifetime and thermal stability of the catalyst as the methane conversion has improved significantly over $240 \mathrm{~min}$ of TOS. Copyright (C) 2016 BCREC GROUP. All rights reserved

Keywords: Methane cracking; TCD; Metal catalysts; Co-precipitation; Nobel metal

How to Cite: Mei, I.L.S., Lock, S.S.M., Vo, D.V.N., Abdullah, B. (2016). Thermo-Catalytic Methane Decomposition for Hydrogen Production: Effect of Palladium Promoter on Ni-based Catalysts. Bulletin of Chemical Reaction Engineering \& Catalysis, 11 (2): 191-199 (doi:10.9767/bcrec.11.2.550.191-199)

Permalink/DOI: http://dx.doi.org/10.9767/bcrec.11.2.550.191-199

\section{Introduction}

Hydrogen is one of the most promising and sustainable clean energy sources because the combustion of hydrogen for energy production only produces water and does not contribute to-

* Corresponding Author.

E-mail: bawadi_abdullah@petronas.com.my (B. Abdullah)

Tel.: +605-3687633, Fax:+605-3654075 wards any greenhouse gases emission to the atmosphere [1]. In addition, the most promising application of hydrogen is for the development of fuel cell, which is a device to convert chemical energy into electricity and heat energy to power automobiles [2]. Hence, extensive research has been performed for the development of cost effective, efficient and safe technology for mass hydrogen production to meet the large global demand for hydrogen. 
Among the hydrogen production technologies, steam methane reforming (SMR) is the most frequently route used to produce hydrogen because the process has high efficiency, low heating value and low operating cost. However, the drawback of using the SMR technology is that it is not environmental-friendly due to the generation of high quantities of greenhouse gases (GHG), which is estimated to be $13.7 \mathrm{~kg}$ of $\mathrm{CO}_{2}$ for every $\mathrm{kg}$ of hydrogen produced [3].

The recent discovery that methane can be directly decomposed into hydrogen and carbon nanofibers has drawn the attention for pure hydrogen production through methane thermocatalytic decomposition (TCD) process, also known as the methane catalytic cracking reaction. According to Wang and Lua [4], this process is feasible because it does not produce $\mathrm{CO}$ or $\mathrm{CO}_{2}$ as by-products and do not require watergas shift and additional separation stages to remove $\mathrm{CO}_{2}$ as compared to the traditional hydrogen production method, which lead to additional economic savings. The carbon produced as by-products during the operation also has advanced properties to be utilized as promising sorbents, catalyst supports and carbonaceous composite materials [4].

Although methane decomposition reaction is an attractive alternative for producing clean energy fuel, it is a moderately endothermic reaction. Non-catalytic decomposition of methane can only happen at extremely high temperature $\left(>1300{ }^{\circ} \mathrm{C}\right)$ to obtain reasonable yield of hydrogen due to the strong $\mathrm{C}-\mathrm{H}$ bonding within methane. Recently, methane decomposition over catalysts has gained high attention as an alternative route for hydrogen production at lower temperature [5-9]. Among the supported metal catalysts which have been investigated by researchers, Ni-based catalysts have been discovered to be an effective catalytic component for many applications such as dry reforming, steam reforming, TCD and etc. [10]. In particular to the methane cracking process, $\mathrm{Ni}$ based catalysts generate promising yield of hydrogen per mass unit of the active component at temperature above $800{ }^{\circ} \mathrm{C}$. However, the hydrogen yield is low $(<40 \%)$ due to thermodynamic limitation for hydrogen production at temperature below $800{ }^{\circ} \mathrm{C}$. In addition, another challenge is that the catalyst deactivates very fast due to an encapsulating type of carbon depositing on the active sites of the catalyst [1114].

The recent study by Srilatha et al. [15] has revealed the potential for $\mathrm{Pd}$ to increase the catalytic lifetime of catalysts for methane decomposition process. However, the effect of the addition of $\mathrm{Pd}$ onto $\mathrm{Ni} / \mathrm{Al}_{2} \mathrm{O}_{3}$ catalysts and the properties of the Ni-Pd alloy which is formed is yet to be investigated by researchers. Hence, in this present work, methane decomposition process over 2 wt.\% Ni supported on alumina, 2 wt.\% Pd supported on alumina, and 1 wt.\% Ni 1 wt.\% Pd supported on alumina (sample coded as $\mathrm{Ni} / \mathrm{Al}_{2} \mathrm{O}_{3}, \mathrm{Pd} / \mathrm{Al}_{2} \mathrm{O}_{3}$ and Ni-Pd/ $/ \mathrm{Al}_{2} \mathrm{O}_{3}$, respectively) was thoroughly studied at 800,700 and $600{ }^{\circ} \mathrm{C}$, respectively. These catalysts were prepared by co-precipitation technique. The effect of introducing Pd as a promoter on Nickel supported Alumina catalyst and reaction temperature on the catalytic reactivity and lifetime was studied in a fixed bed system for $10 \mathrm{~mL} / \mathrm{min}$ flow of methane gas. In addition, the synthesized catalyst were characterized by the application of scanning electron microscopy (SEM), Brunauer Emmett and Teller (BET) surface area analysis, X-Ray Diffraction (XRD), Temperature Programmed Reduction (TPR) and Thermogravimetric Analysis (TGA) to compare their morphologies and physico-chemical properties.

\section{Materials and Methods}

\subsection{Materials}

The chemicals which are used for the synthesize of the catalysts are aluminum nitrate nonahydrate (98 wt.\% purity; Sigma-Aldrich); nickel(II) nitrate hexahydrate (99 wt.\% purity; Merck Millipore) and palladium(II) chloride (99 wt.\% purity; ReagentPlus) and ammonia solution (5 wt.\% purity; Merck Millipore). In addition, highly pure methane gas (99.99 wt.\% purity; Sigma-Aldrich) and argon gas (99.88 wt.\% purity; Sigma-Aldrich) are used as the reactor influent to evaluate the catalytic activity and performance of the synthesized catalysts.

\subsection{Preparation of catalysts}

The catalysts were prepared by using the coprecipitation method. The co-precipitation technique involved the homogeneous mixing of nickel, palladium and aluminum precursor solution, and modifying the $\mathrm{pH}$ of the solution to precipitate the catalysts out from the mixture by the addition of alkaline solution. Aqueous solution of nickel nitrate hexahydrate $\left(\mathrm{Ni}\left(\mathrm{NO}_{3}\right)_{2} \cdot 6 \mathrm{H}_{2} \mathrm{O}\right)$, and palladium(II) chloride $\left(\mathrm{PdCl}_{2}\right)$ were titrated drops by drops into aluminum nitrate nanohydrate $\left(\mathrm{Al}\left(\mathrm{NO}_{3}\right)_{3} .9 \mathrm{H}_{2} \mathrm{O}\right)$ solution to enable homogeneous mixing. Next, the mixture was stirred at $60{ }^{\circ} \mathrm{C}$ while ammonia solution $\left(\mathrm{NH}_{3} \mathrm{H}_{2} \mathrm{O}\right)$ was added by drop wise to increase the $\mathrm{pH}$ of the solution to 10 . Then, the 
solution was heated to $100{ }^{\circ} \mathrm{C}$ and the solution was stirred for 1 hour at $300 \mathrm{rpm}$. The $\mathrm{Ni}$ $\mathrm{Pd} / \mathrm{Al}_{2} \mathrm{O}_{3}$ catalyst will start to precipitate out of the solution and the slurry was filtered and washed with deionized water to remove excess ammonia solution. This was followed by drying the catalyst overnight in an oven at $100{ }^{\circ} \mathrm{C}$ and the calcination of the catalysts at $600{ }^{\circ} \mathrm{C}$ for 6 hours with air.

\subsection{TCD of methane-catalytic activity test- ing}

The catalytic activity, thermal stability and deactivation rate of the synthesized catalysts were evaluated at atmospheric pressure on a conventional fixed bed gas flow system with $500 \mathrm{mg}$ of catalysts using a single-zone furnace (Carbolite VST 12) without end insulation. The methane decomposition test rig consists of 3 main components, which are the gas mixing system, the fixed bed reactor for methane cracking process to take place and an online gas chromatography system. The test rig for thermo-catalytic methane decomposition reaction is indicated in Figure 1. Before the experimental work is conducted, pure argon gas at 20 $\mathrm{mL} / \mathrm{min}$ was allowed to flow through the reactor to create an inert atmosphere in the reactor. Next, the co-precipitated catalysts were subjected to reduction pre-treatment with hydrogen gas at $30 \mathrm{~mL} / \mathrm{min}$ at $600{ }^{\circ} \mathrm{C}$ for 1 hour. After reduction, the reactor was flushed with pure argon gas until the gas chromatography system showed no existence of hydrogen gas.

During the experiment, $10 \mathrm{~mL} / \mathrm{min}$ of methane gas was diluted with $5 \mathrm{~mL} / \mathrm{min}$ of argon gas in the gas mixing system before the gas mixture is introduced into the reactor. The flow of methane, hydrogen and argon gas can be regulated by a mass flow controller is located at the inlet stream to the reactor. The temperature of the catalyst bed was measured and monitored by using a thermocouple and temperature controller which is connected directly to the reactor. The reactor effluent is analyzed by using an online gas chromatography system (Hewlett Packard Series 6890) which is located at the outlet of the reactor. The exit stream was analyzed every 15 minutes for a total reaction time of 4 hours and the catalysts were tested at 600,700 , and $800{ }^{\circ} \mathrm{C}$, respectively while the flow rate of methane and gas were maintained at constant value.

For every 15 minutes interval, GC analysis measured the percentage (v/v) composition of the reactor effluent stream and percentage of methane conversion against time were investigated for all the trials. The conversion of methane and the yield of hydrogen are defined and calculated as explained by Mohd Zabidi et al. [16].

\subsection{Catalyst characterization}

The catalysts were analyzed by scanning

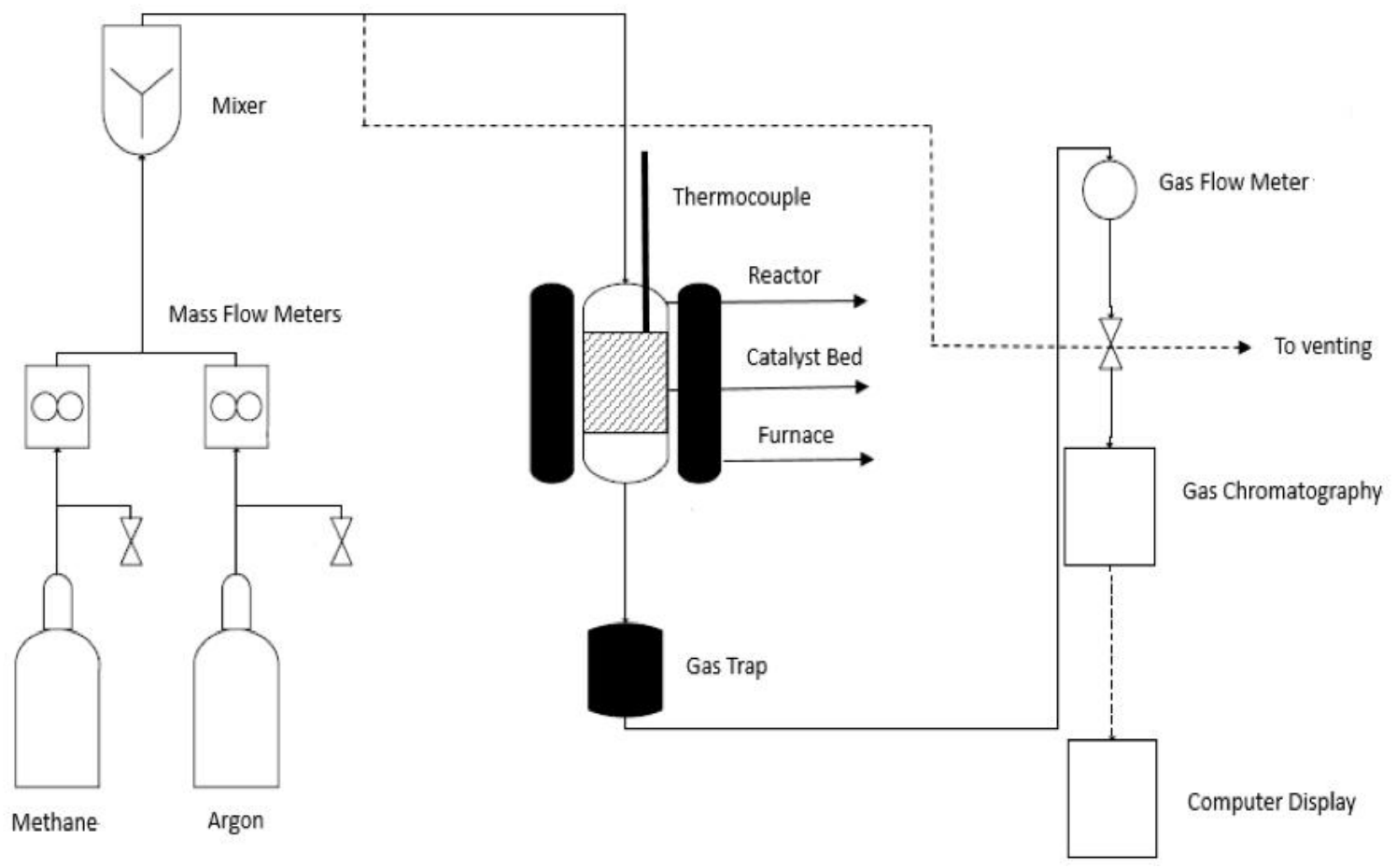

Figure 1. Experimental rig for thermo-catalytic methane decomposition study 
electron microscopy (SEM) to study the surface morphology of the fresh catalysts. The SEM images were taken by using Phillips XL30/FEI ESEM system which was operated at an accelerating voltage from 5 to $30 \mathrm{kV}$. In addition, the $\mathrm{N}_{2}$ adsorption-desorption isotherms for the synthesized catalysts were measured on a Micromeritics ASAP 2020 system. All the samples were evacuated at $300{ }^{\circ} \mathrm{C}$ in vacuum to remove water and other contaminants prior to the measurement. From $\mathrm{N}_{2}$ adsorption and desorption isotherms at $-196{ }^{\circ} \mathrm{C}(77 \mathrm{~K})$, the catalysts can be characterized for the determination of the specific surface area and pore volume.

Besides that, powder X-ray diffraction (XRD) spectra were recorded on a Bruker D8 Advance (USA) X-ray diffractometer by using $\mathrm{Cu}$ Ka1 radiation $(\lambda=1.54 \AA)$ at $40 \mathrm{kV}$ tube voltage and $40 \mathrm{~mA}$ tube current with a scanning speed of $2^{\circ}$ per minute between $20^{\circ}$ and $80^{\circ} 2 \theta$. The XRD patterns recorded were referenced and compared with the power diffraction database for phase identification.

The reducibility behavior of the catalysts were also investigated by the application of $\mathrm{H}_{2}$ Temperature Program Reduction technique on a Thermo Finnigan (TPRRO 1100) equipment. Prior to $\mathrm{H}_{2}$ reduction, the samples were pretreated with nitrogen at $300{ }^{\circ} \mathrm{C}$ with a flow rate of $20 \mathrm{~mL} / \mathrm{min}$ and ramping rate of $10^{\circ} \mathrm{C} / \mathrm{min}$ and finally holding at $300{ }^{\circ} \mathrm{C}$ for 30 minutes to eliminate any impurities. TPR analysis was then conducted in $5 \% \mathrm{H}_{2} / \mathrm{N}_{2}$ with a flow rate of $20 \mathrm{~mL} / \mathrm{min}$. The samples were heated with a ramping rate of $10{ }^{\circ} \mathrm{C} / \mathrm{min}$ from room temperature to $800{ }^{\circ} \mathrm{C}$ and the reduction profile was determined.
The catalysts were also characterized by using Thermogravimetric Analysis (TGA) to investigate the weight loss, thermal behavior and structural decomposition of the samples at a heating rate of $10{ }^{\circ} \mathrm{C} / \mathrm{min}$ up to $800{ }^{\circ} \mathrm{C}$. The weight of the samples were initially at $0.1 \mathrm{~g}$ and was performed under sweeping air atmosphere at $10 \mathrm{~mL} / \mathrm{min}$.

\section{Results and Discussion}

\subsection{Characterization of calcined catalysts}

The Scanning Electron Micrographs at 10,000 magnification are presented in Figure 2. The SEM image of the samples after calcination shows that a porous sponge-like structure, consisting of pyramid-shaped and rod-shaped particles has been formed. However, the particles size are significantly smaller for the Ni-Pd/Al $\mathrm{Al}_{2} \mathrm{O}_{3}$ catalyst and $\mathrm{Ni} / \mathrm{Al}_{2} \mathrm{O}_{3}$ catalyst than the $\mathrm{Pd} / \mathrm{Al}_{2} \mathrm{O}_{3}$ catalyst. In addition, the surface areas and pore volumes which were determined by $\mathrm{N}_{2}$ physisorption for the synthesized catalysts are given in Table 1. The adsorption isotherms are indicated in Figure 3. The specific surface areas for the synthesized catalysts varied between 195.31 and $212.80 \mathrm{~m}^{2} / \mathrm{g}$ while the pore volume varied between 0.30 and $0.38 \mathrm{~cm}^{3} / \mathrm{g}$. The inhouse prepared $\mathrm{Ni}-\mathrm{Pd} / \mathrm{Al}_{2} \mathrm{O}_{3}$ catalyst demonstrated higher surface area and wider pore volume as compared to the co-precipitated $\mathrm{Ni} / \mathrm{Al}_{2} \mathrm{O}_{3}$ and $\mathrm{Pd} / \mathrm{Al}_{2} \mathrm{O}_{3}$ catalysts. The development of high surface area catalysts are significant to achieve high diffusion and mass transfer rate during the methane decomposition process, contributing to higher catalytic activity and reaction rate. In addition, larger pore volumes might be feasible

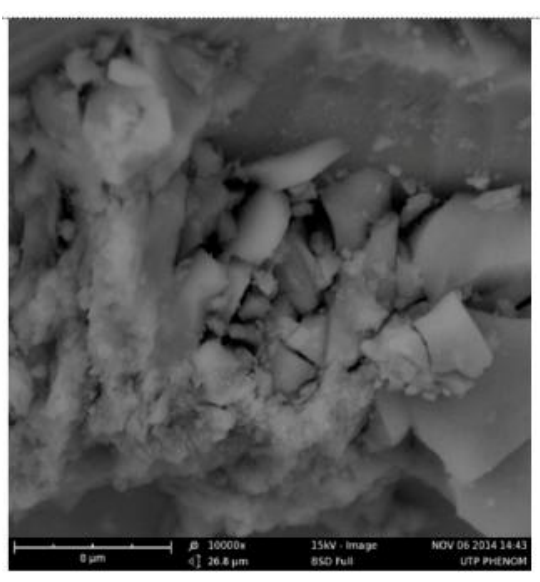

(a)

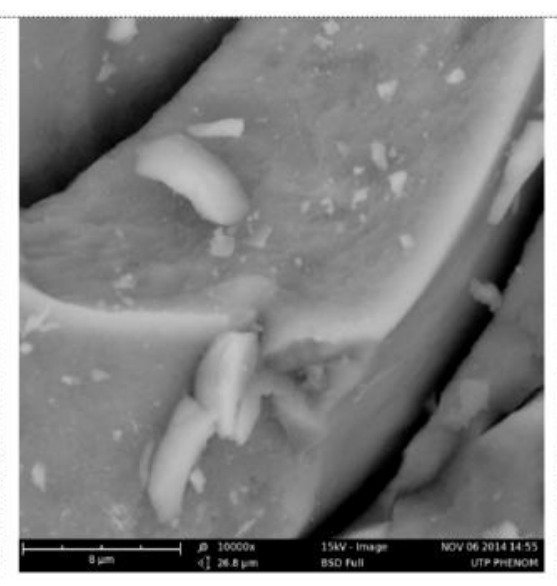

(b)

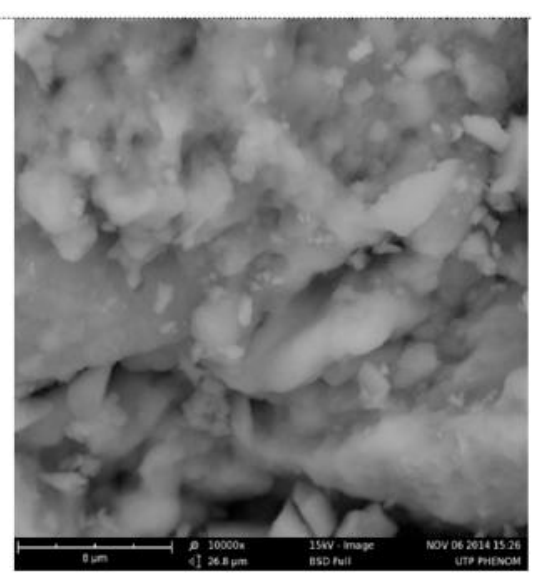

(c)

Figure 2. SEM images of synthesized catalysts after calcination at $10,000 \times$ magnification: (a) $\mathrm{Ni} / \mathrm{Al}_{2} \mathrm{O}_{3}$, (b) $\mathrm{Pd} / \mathrm{Al}_{2} \mathrm{O}_{3}$, and (c) $\mathrm{Ni}-\mathrm{Pd} / \mathrm{Al}_{2} \mathrm{O}_{3}$ 
for rapid molecular transportation, namely higher diffusion efficiency of reactants and products and to avoid the blockage of the active sites of the catalyst due to carbon deposition during the reaction.

The XRD pattern for the calcined $\mathrm{Ni} / \mathrm{Al}_{2} \mathrm{O}_{3}$, $\mathrm{Pd} / \mathrm{Al}_{2} \mathrm{O}_{3}$ and $\mathrm{Ni}-\mathrm{Pd} / \mathrm{Al}_{2} \mathrm{O}_{3}$ catalysts are shown in Figure 4. Based on the XRD spectrum for $\mathrm{Ni} / \mathrm{Al}_{2} \mathrm{O}_{3}$ catalyst, the peak observed at $2 \theta=$ $65.3^{\circ}$ corresponded to the formation of defect $\mathrm{NiAl}_{2} \mathrm{O}_{4}$ spinel phase. This is because the peak value is detected between the values of $2 \theta=$ $67.3^{\circ}$ for $\gamma-\mathrm{Al}_{2} \mathrm{O}_{3}$ and $2 \theta=65^{\circ}$ for stoichiometric $\mathrm{NiAl}_{2} \mathrm{O}_{4}$ spinel. The other peaks for the defect $\mathrm{NiAl}_{2} \mathrm{O}_{4}$ phase occur at values of approximately $2 \theta=36^{\circ}, 45.8^{\circ}, 59.7^{\circ}$ and $65.3^{\circ}$. The peaks observed at $2 \theta=36^{\circ}, 45.8^{\circ}$ and $65.3^{\circ}$ corresponded to the formation of $\gamma-\mathrm{Al}_{2} \mathrm{O}_{3}$ lattice while $\mathrm{NiO}$ is only detected at the first peak at $2 \theta=36^{\circ}$. This may be due to the reason that XRD can typically only detect metal crystallites that are larger than $2-5 \mathrm{~nm}$ and $\mathrm{NiO}$ crystallite sizes are smaller than the detection limit [17].

In addition, XRD patterns of $\mathrm{Pd} / \mathrm{Al}_{2} \mathrm{O}_{3}$ shows six diffraction peaks. Among these six peaks,

Table 1. Surface area and pore volumes for catalysts

\begin{tabular}{ccc}
\hline $\begin{array}{c}\text { Type of } \\
\text { catalysts }\end{array}$ & $\begin{array}{c}\text { Surface } \\
\text { Area }\left(\mathrm{m}^{2} / \mathrm{g}\right)\end{array}$ & $\begin{array}{c}\text { Pore Volume } \\
\left(\mathrm{cm}^{3} / \mathrm{g}\right)\end{array}$ \\
\hline $\mathrm{Ni} / \mathrm{Al}_{2} \mathrm{O}_{3}$ & 201.03 & 0.34 \\
$\mathrm{Pd} / \mathrm{Al}_{2} \mathrm{O}_{3}$ & 195.31 & 0.30 \\
$\mathrm{Ni}-\mathrm{Pd} / \mathrm{Al}_{2} \mathrm{O}_{3}$ & 212.80 & 0.38 \\
\hline
\end{tabular}

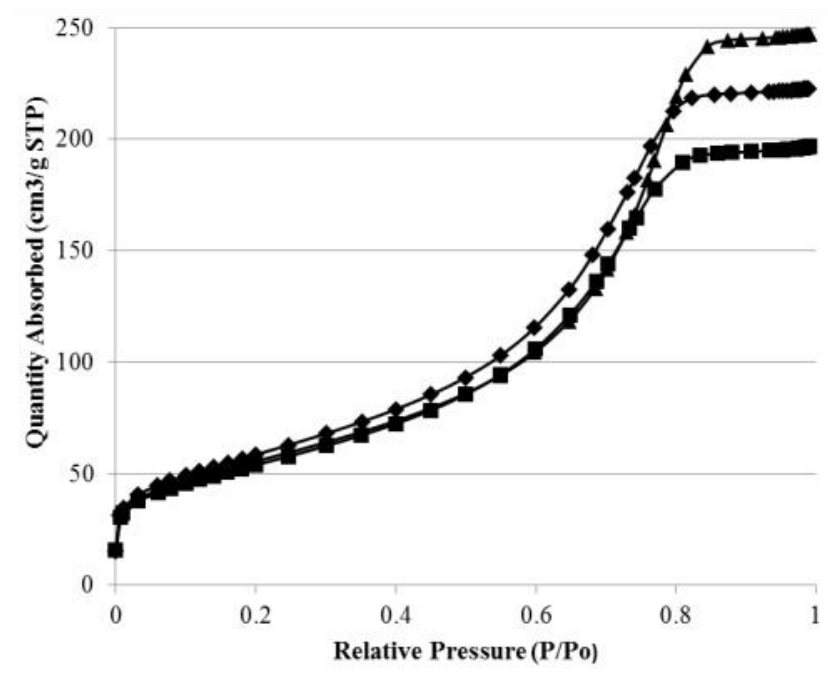

Figure 3. $\mathrm{N}_{2}$ adsorption isotherms of catalysts at $-196{ }^{\circ} \mathrm{C}$. Symbols represent: $(\diamond) \mathrm{Ni}-\mathrm{Pd} / \mathrm{Al}_{2} \mathrm{O}_{3}$ cata-

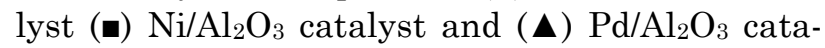

Pd peaks appeared at $2 \theta$ angles of $33^{\circ}, 40^{\circ}$, $45.8^{\circ}$ and $69^{\circ}$, while the angles at $36^{\circ}, 45.8^{\circ}$ and $65.3^{\circ}$, representing $\gamma-\mathrm{Al}_{2} \mathrm{O}_{3}$ formation. This finding is almost similar to the $\gamma-\mathrm{Al}_{2} \mathrm{O}_{3}$ phase observed for co-precipitated $\mathrm{Ni} / \mathrm{Al}_{2} \mathrm{O}_{3}$ catalyst. Interestingly, the diffraction peak detected at $33^{\circ}$ was due to $\mathrm{Pd}$ formation in its oxide form $(\mathrm{PdO})$. The XRD spectra suggested the existence of pure $\mathrm{Pd}{ }^{\circ}$ along with $\mathrm{PdO}$ nanoparticles in the $\mathrm{Pd} / \mathrm{Al}_{2} \mathrm{O}_{3}$ sample. On the other hand, XRD profile of Ni-Pd/Al $/ \mathrm{O}_{3}$ showed eight diffraction peaks with $\mathrm{Pd}$ peaks observed at $2 \theta$ angles of $40^{\circ}, 45^{\circ}$ and $69^{\circ}$. The diffraction peaks at $2 \theta=35.1^{\circ}, 45^{\circ}, 48^{\circ}$ and $63^{\circ}$ corresponded to the formation of $\gamma-\mathrm{Al}_{2} \mathrm{O}_{3}$ phase while $\mathrm{Ni}$ peaks were detected at $35.1^{\circ}, 48^{\circ}, 51^{\circ}, 60^{\circ}$ and $63^{\circ}$. The XRD spectra for the $\mathrm{Ni}-\mathrm{Pd} / \mathrm{Al}_{2} \mathrm{O}_{3}$ sample demonstrated a unique profile which is distinct from that which should be observed from a simple combination of the XRD profiles recorded for the monometallic catalysts. The XRD profile of the sample suggested that alloyed NiPd species has been formed within the catalyst, which is favorable and beneficial for the thermo-catalytic methane decomposition process.

The TPR profiles of the samples are shown in Figure 5 to study the metal-support interaction. For the Ni/Al $\mathrm{O}_{3}$ catalyst, two zones of reduction peaks are presented. The first zone is observed at the temperature of $400{ }^{\circ} \mathrm{C}$ while the second reduction peak is observed at the temperature range between 600 to $700{ }^{\circ} \mathrm{C}$. The reduction peak at lower temperature correspond to the reduction of $\mathrm{NiO}$ species which has minimal interaction with the alumina support. The higher temperature reduction peak may be attributed to the strong interaction of spinel $\mathrm{NiAl}_{2} \mathrm{O}_{4}$ phase. The formation of a

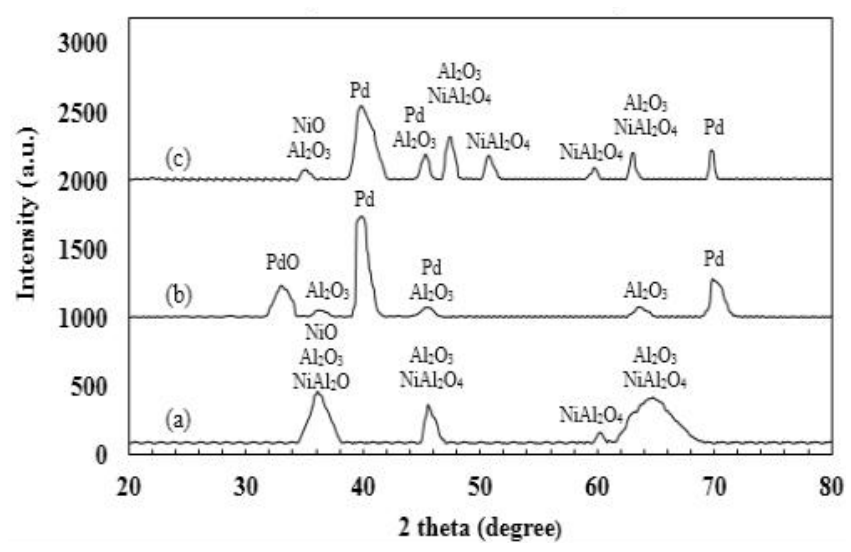

Figure 4. XRD diffractograms of synthesized catalysts. (a) $\mathrm{Ni} / \mathrm{Al}_{2} \mathrm{O}_{3}$ catalyst, (b) $\mathrm{Pd} / \mathrm{Al}_{2} \mathrm{O}_{3}$ catalyst and (c) Ni-Pd/Al ${ }_{2} \mathrm{O}_{3}$ catalyst 
strong interaction of $\mathrm{NiAl}_{2} \mathrm{O}_{4}$ was confirmed by the XRD spectra of $\mathrm{Ni} / \mathrm{Al}_{2} \mathrm{O}_{3}$ sample and was also reported by other researchers within the temperature range of $550{ }^{\circ} \mathrm{C}$ and $750{ }^{\circ} \mathrm{C}$ [1820]. For the $\mathrm{Pd} / \mathrm{Al}_{2} \mathrm{O}_{3}$ catalyst, the TPR traces exhibited a main hydrogen consumption peak due to the reduction of $\mathrm{PdO}$ species to metallic palladium. Another reduction peak is observed at $450{ }^{\circ} \mathrm{C}$ which could be attributed to $\mathrm{Pd}$ alumina support interactions and a strong support de-hydroxylation. The TPR profile was similar to those reported by Garcia et al. [20] for $\mathrm{Pd}$ supported on alumina catalysts. On the other hand, the TPR profile of the bimetallic $\mathrm{Ni}-\mathrm{Pd} / \mathrm{Al}_{2} \mathrm{O}_{3}$ is very similar to those corresponding to the monometallic $\mathrm{Pd}$. The $\mathrm{Ni}-\mathrm{Pd} / \mathrm{Al}_{2} \mathrm{O}_{3}$ first peak is at the range of 100 to $200{ }^{\circ} \mathrm{C}$ which is due to the reduction of $\mathrm{PdO}$ and a second peak at the range of 300 to $600{ }^{\circ} \mathrm{C}$ which may be due to the reduction of $\mathrm{NiAl}_{2} \mathrm{O}_{4}$ species, which were formed by the diffusion of $\mathrm{Ni}^{2+}$ into the support. The results is similar to those reported by Lederhos et al. [22]. It can be observed that the presence of nickel shifted the peaks of $\mathrm{NiO}$ from $700{ }^{\circ} \mathrm{C}$ to lower temperature range, suggesting that the $\mathrm{Ni}-\mathrm{Pd} / \mathrm{Al}_{2} \mathrm{O}_{3}$ catalyst is easier to be reduced.

Figure 6 indicates the relationship between the residual sample weight percentages with the decomposition temperature for all synthesized catalysts. All the samples demonstrated similar TGA traces in which the weight loss increases as the temperature increases. The total weight loss of these co-precipitated catalysts varied within 84 to $86 \%$. However, the $\mathrm{Ni}$ $\mathrm{Pd} / \mathrm{Al}_{2} \mathrm{O}_{3}$ catalyst demonstrated higher resistance towards decomposition at high temperature with total weight loss of only $14 \%$ as com-

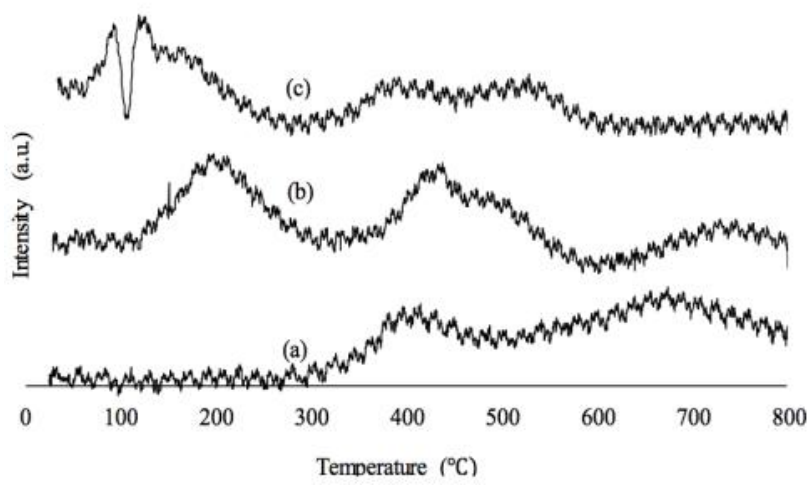

Figure 5. Temperature-programmed reduction profiles of synthesized catalysts: a) $\mathrm{Ni} / \mathrm{Al}_{2} \mathrm{O}_{3}$, (b) $\mathrm{Pd} / \mathrm{Al}_{2} \mathrm{O}_{3}$ and (c) $\mathrm{Ni}-\mathrm{Pd} / \mathrm{Al}_{2} \mathrm{O}_{3}$; heating rate of 10 ${ }^{\circ} \mathrm{C} / \mathrm{min}$ in $5 \% \mathrm{H}_{2}$ in $\mathrm{N}_{2}$ pared to $\mathrm{Ni} / \mathrm{Al}_{2} \mathrm{O}_{3}(15 \%)$ and $\mathrm{Pd} / \mathrm{Al}_{2} \mathrm{O}_{3}(\sim 16 \%)$. The finding suggested that the incorporation of $\mathrm{Pd}$ onto $\mathrm{Ni}$ based catalyst may improve the thermal stability of the catalyst. This finding is significant because the catalyst should be able to have long-term and high thermal stability to prevent the decomposition and deactivation of the catalysts during methane cracking reaction.

\subsection{Catalytic activity of catalysts for methane decomposition process}

The methane conversion profile for the synthesized catalysts as a function of time for thermo-catalytic methane decomposition within 4 hours on stream at 600, 700, and 800 ${ }^{\circ} \mathrm{C}$, respectively and the results are shown in Figure 7. The effect of introducing $\mathrm{Pd}$ as a promoter to Nickel supported on alumina catalyst were investigated through the experimental work by comparing and evaluating the performance of the synthesized catalysts which can provide high methane conversion with long-term operational lifetime. The experimental results suggested that as the reaction temperature is higher, the catalytic activity also improved significantly. The experimental studies indicated that methane conversion values were the lowest at $\mathrm{T}=600{ }^{\circ} \mathrm{C}$ for all the synthesized catalysts due to the reduced amount of energy available to break the $\mathrm{C}-\mathrm{H}$ bonding within methane into hydrogen.

The experimental results also indicates that the methane conversion decreases over time due to carbon deposition on the active sites of the catalysts, resulting in sintering and deactivation of the catalysts during the operation. This results is consistent with the observation

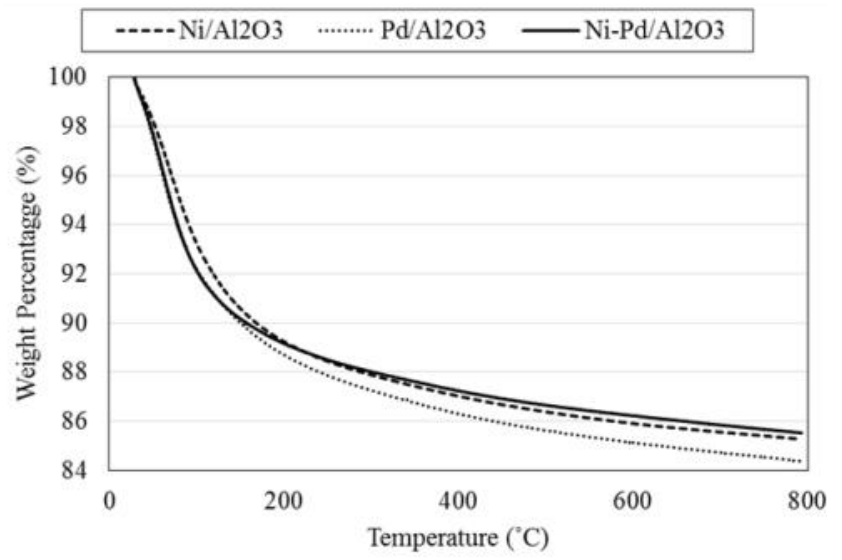

Figure 6. Thermo-gravimetric analysis of synthesized catalysts; heating rate of $10{ }^{\circ} \mathrm{C} / \mathrm{min}$ in sweeping air atmosphere at $10 \mathrm{~mL} / \mathrm{min}$ 
and findings which were obtained from other studies in which the catalytic activity of the catalysts decrease rapidly within 2 hours on stream even though the initial hydrogen production rate was promising [11, 23-24].

The methane conversion obtained for all the synthesized catalyst within 15 min on stream are summarized in Table 2. The experimental results indicate that when $\mathrm{Ni} / \mathrm{Al}_{2} \mathrm{O}_{3}$ catalyst is used for the methane cracking process without introducing $\mathrm{Pd}$ as a promoter, the methane conversion at $800{ }^{\circ} \mathrm{C}$ is at $47 \%$. At $700{ }^{\circ} \mathrm{C}$, the methane conversion is approximately $38 \%$ while the methane conversion is only $27 \%$ at $600{ }^{\circ} \mathrm{C}$. The methane conversion is the lowest for $\mathrm{Pd} / \mathrm{Al}_{2} \mathrm{O}_{3}$ catalysts in which the methane conversion is only at $18 \%$ at $600{ }^{\circ} \mathrm{C}$ and $27 \%$ at $700{ }^{\circ} \mathrm{C}$. However, when $\mathrm{Pd}$ is introduced as promoter onto the nickel-based catalysts, the methane conversion has improved significantly from $47 \%$ to $66 \%$ at $800{ }^{\circ} \mathrm{C}$, from $38 \%$ to $56 \%$ at $700{ }^{\circ} \mathrm{C}$ and from $27 \%$ to $42 \%$ at $600{ }^{\circ} \mathrm{C}$.

The experimental results suggested that the formation of a strong Ni-Pd alloy bonding within the alumina-supported catalysts is beneficial for methane cracking process. This is because the formation of the $\mathrm{Ni}-\mathrm{Pd}$ bonding increases the catalytic activity of the catalysts,

Table 2. Methane conversion within 15 min on stream

\begin{tabular}{cccc}
\hline \multirow{2}{*}{ Catalyst } & \multicolumn{3}{c}{ Conversion (\%) } \\
\cline { 2 - 4 } & $600{ }^{\circ} \mathrm{C}$ & $700{ }^{\circ} \mathrm{C}$ & $800{ }^{\circ} \mathrm{C}$ \\
\hline $\mathrm{Ni} / \mathrm{Al}_{2} \mathrm{O}_{3}$ & 27.41 & 37.91 & 47.12 \\
$\mathrm{Pd} / \mathrm{Al}_{2} \mathrm{O}_{3}$ & 18.23 & 22.89 & 35.61 \\
$\mathrm{Ni}-\mathrm{Pd} / \mathrm{Al}_{2} \mathrm{O}_{3}$ & 42.18 & 56.82 & 66.88 \\
\hline
\end{tabular}

which can catalyze a greater number of methane molecules to hydrogen and carbon.

The methane conversion for the synthesized catalysts after they have been used for $240 \mathrm{~min}$ on stream are summarized in Table 3. It can be observed that the methane conversion after 4 hours on-stream for $\mathrm{Ni}-\mathrm{Pd} / \mathrm{Al}_{2} \mathrm{O}_{3}$ catalyst are higher than the methane conversion which is obtained for the monometallic supported on alumina catalyst. This is attributed to the presence of $\mathrm{Pd}$ within the structure of the catalysts, which has enhanced the thermal stability of the catalyst at elevated temperature by reducing the tendency for deactivation due to coking and sintering. The co-precipitated Ni$\mathrm{Pd} / \mathrm{Al}_{2} \mathrm{O}_{3}$ catalyst remained active (conversion> $20 \%$ ) although it has been used on-stream for 4 hours. This maybe due to the higher surface area and homogeneous morphology of the catalyst resulted in an improved capability of the catalyst to accumulate carbon, thus contributing towards higher operational lifetime of the catalysts by making it less susceptible to deactivation and coking. In addition, the uniform dispersion of $\mathrm{Ni}$ and $\mathrm{Pd}$ particles which can be observed from the SEM images enables higher interaction between the catalyst and methane to take place, even when some of the active

Table 3. Methane conversion within 240 min on stream

\begin{tabular}{cccc}
\hline \multirow{2}{*}{ Catalyst } & \multicolumn{3}{c}{ Conversion (\%) } \\
\cline { 2 - 4 } & $600{ }^{\circ} \mathrm{C}$ & $700{ }^{\circ} \mathrm{C}$ & $800{ }^{\circ} \mathrm{C}$ \\
\hline $\mathrm{Ni} / \mathrm{Al}_{2} \mathrm{O}_{3}$ & 6.03 & 11.24 & 15.33 \\
$\mathrm{Pd} / \mathrm{Al}_{2} \mathrm{O}_{3}$ & 5.59 & 10.23 & 15.68 \\
$\mathrm{Ni}-\mathrm{Pd} / \mathrm{Al}_{2} \mathrm{O}_{3}$ & 15.55 & 20.31 & 24.56 \\
\hline
\end{tabular}

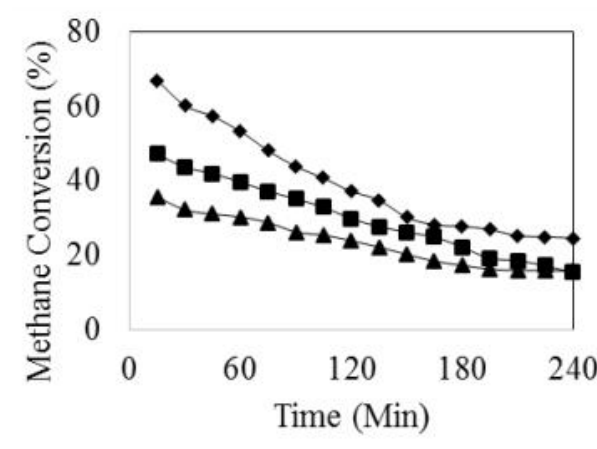

(a)

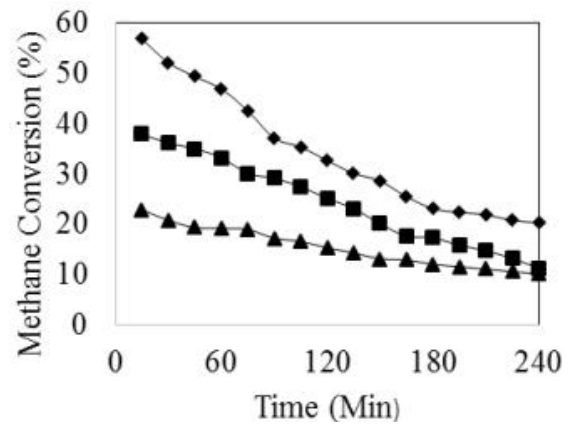

(b)

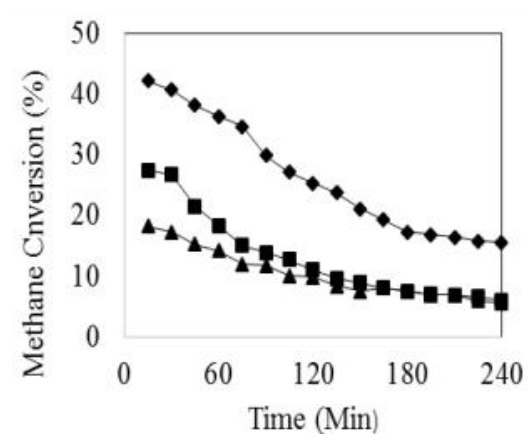

(c)

Figure 7. Percentage of methane conversion against time at (a) $800{ }^{\circ} \mathrm{C}$, (b) $700{ }^{\circ} \mathrm{C}$ and (c) $600{ }^{\circ} \mathrm{C}$. Symbols represent: $(\diamond) \mathrm{Ni}-\mathrm{Pd} / \mathrm{Al}_{2} \mathrm{O}_{3}$ catalyst $(\boldsymbol{\bullet}) \mathrm{Ni} / \mathrm{Al}_{2} \mathrm{O}_{3}$ catalyst and $(\boldsymbol{\Delta}) \mathrm{Pd} / \mathrm{Al}_{2} \mathrm{O}_{3}$ catalyst 
sites of the catalyst has been blocked by carbon particles.

\section{Conclusions}

The results of the study suggested that the addition of $\mathrm{Pd}$ on $\mathrm{Ni} / \mathrm{Al}_{2} \mathrm{O}_{3}$ catalysts for the thermo-catalytic methane decomposition has a significant effect on the catalytic activity and thermal stability of the catalyst at high temperature. The $2 \% \mathrm{Ni} / \mathrm{Al}_{2} \mathrm{O}_{3}$ catalyst without $\mathrm{Pd}$ loading rapidly deactivated due to the formation of condensed encapsulating carbon during the methane cracking process which can block the activation sites of the catalyst. On the other hand, the $1 \% \mathrm{Ni}-1 \% \mathrm{Pd} / \mathrm{Al}_{2} \mathrm{O}_{3}$ was stable throughout the methane decomposition process with a lower deactivation rate. The finding suggested that an increase in stability at elevated temperature is attributed to the addition of $\mathrm{Pd}$ as a promoter onto the surface of the coprecipitated catalyst. The interaction of Pd particles with the metallic $\mathrm{Ni}$ particles resulted in an enhanced ability to suppress carbon formation, thus increasing the catalytic lifetime of the catalyst.

\section{Acknowledgement}

The authors gratefully acknowledged the financial support from Ministry of Higher Education (MOHE) Malaysia in the form of Fundamental Research Grant Scheme (FRGS) (Grant No: 0153AB-K22). We thank UTP for providing a congenial work environment and state-of-theart research facilities.

\section{References}

[1] Abbas, H., Wan Daud, W. (2010). Hydrogen Production by Methane Decomposition: A Review. International Journal of Hydrogen Energy, 35: 1160-1190.

[2] Lesmana, D., Wu, H. S. (2012). Short Review: $\mathrm{Cu}$ Catalyst for Autothermal Reforming Methanol for Hydrogen Production. Bulletin of Chemical Reaction Engineering \& Catalysis, 7: 27-42.

[3] Wu, H., Parola, V., Pantaleo, G., Puleo, F. (2013). Ni-based Catalysts for Low Temperature Methane Steam Reforming: Recent Results on Ni-Au and Comparison with Other Bi-metallic Systems. Catalysts, 3: 563-583.

[4] Wang, H., Lua, A. (2013). Hydrogen Production by Thermocatalytic Methane Decomposition. Heat Transfer Engineering, 34(11-12): 896-903.

[5] Awadallah, A., Mostafa, M., Aboul-Enein, A., Hanafi, S. (2014). Hydrogen Production via
Methane Decomposition over $\mathrm{Al}_{2} \mathrm{O}_{3}-\mathrm{TiO}_{2} \mathrm{Bi}$ nary Oxides Supported Ni Catalysts: Effect of Ti Content on The Catalytic Efficiency. Fuel, 129: 68-77.

[6] Zhou, L., Guo, Y., Hideo, K. (2014). Unsupported Nickel Catalysts for Methane Catalytic Decomposition into Pure Hydrogen. AICHE Journal, 60(8): 2907-2917

[7] Jin, L., Si, H., Zhang, J., Lin, P., Hu, Z., Qiu, B. (2013). Preparation of Activated Carbon Supported $\mathrm{Fe}-\mathrm{Al}_{2} \mathrm{O}_{3}$ and Its Application for Hydrogen Production by Catalytic Methane Decomposition. International Journal of Hydrogen Energy, 38(25): 10373-10380.

[8] Ahmed, S. (2013). Catalytic Decomposition of Methane for Hydrogen Production Using Different Types of Catalysts. Titrit Journal of Engineering Science, 20(5): 19-23.

[9] Wang, G., Jin, Y., Liu, G., Li, Y. (2013). Production of Hydrogen and Nanocarbon from Catalytic Decomposition of Methane over A $\mathrm{Ni}-\mathrm{Fe} / \mathrm{Al}_{2} \mathrm{O}_{3}$ Catalyst. Energy and Fuels, 27 (8): 4448-4456.

[10] Selvarajah, K., Nguyen, H.H.P., Abdullah, B. Alenazey, F., Vo, D-V.N. (2016). Syngas production from methane dry reforming over $\mathrm{Ni} / \mathrm{Al}_{2} \mathrm{O}_{3}$ catalyst. Res. Chem. Intermed, 42(1): 269-288, doi: 10.1007/s11164-015-2395-5

[11] Adrian, L., Abella, L.C., Monroy, T.G. (2014). Hydrogen Production via Thermo Catalytic Decomposition of Methane over Bimetallic Ni-Cu/AC Catalysts: Effect of Copper Loading and Reaction Temperature. International Journal of Chemical Engineering and Application, 3(2): 92-97.

[12] Amin, A., Epling, W., Croiset, E. (2011). Reaction and Deactivation Rates of Methane Catalytic Cracking over Nickel. Industrial \& Engineering Chemistry Research, 50: 12460-12470.

[13] Makvandi, S., Alavi, S. M. (2011). CO Cree Hydrogen Production by Catalytic Decomposition of Methane over Porous $\mathrm{Ni} / \mathrm{Al}_{2} \mathrm{O}_{3}$ Catalysts. Iranian Journal of Chemical Engineering, 8(4): 24-33.

[14] Bai, Z., Chen, H., Li, B, Li. W (2007). Methane Decomposition over Ni loaded Activated Carbon for Hydrogen Production and the Formation of Filamentous Carbon. International Journal of Hydrogen Energy, 32(1): 32-37.

[15] Srilatha, K., Srinivasulu, D., Ramakrishna, S.U.B., Himabindu, V. (2014). Thermo Catalytic Decomposition of Methane over $\mathrm{Pd} / \mathrm{AC}$ and $\mathrm{Pd} / \mathrm{CB}$ Catalysts for Hydrogen Production and Carbon Nanofibers Formation. International Journal of Engineering Research and Applications, 4(9): 81-86.

[16] Shah, N., Panjala, D., Huffman, G.P. (2001). Hydrogen production by catalytic decomposi- 
tion of methane. Energy Fuels, 15(6): 15281534 .

[17] Poncelet, G., Centeno, M., Molina, R. (2005). Characterization of reduced a-aluminasupported nickel catalysts by spectroscopic chemisorption measurement. Applied Catalysis A: General, 288: 232-242.

[18] Yaakob, Z., Bshish, A., Ebshish, A., Tasirin, S.M., Alhasan, F. H. (2013). Hydrogen Production by Steam Reforming of Ethanol over Nickel Catalysts Supported on Sol Gel Made Alumina: Influence of Calcination Temperature on Supports. Journal of Materials, 6: 2229-2239.

[19] Zhang, X., Liu, J., Jing, Y., Xie, Y. (2003). Support Effects on the Catalytic Behavior of $\mathrm{NiO} / \mathrm{Al}_{2} \mathrm{O}_{3}$ for Oxidative Dehydrogenation of Ethane to Ethylene. Applied Catalysis A: General, 240: 143-150.

[20] Negrier, F., Marceau, E., Che, M., de Caro, D. (2003). Role of Ethylenediamine in the Prepartion of Alumina-Supported Ni Catalysts from $\left[\mathrm{Ni}(\mathrm{en})_{2}\left(\mathrm{H}_{2} \mathrm{O}\right)_{2}\right]\left(\mathrm{NO}_{3}\right)_{2}$ : From Solution Properties to Nickel Particles. Comptes Resdus Chimie, 6: 231-240.
[21] Garcia, G., Vargas, J. R., Valenzuela, M.A., Rebollar, M., Acosta, D. (1999). Palladium Supported on Alumina Catalysts Prepared by MOCVD and Impregnation Method. Materials Research Society, 549: 237.

[22] Lederhos, C. R., Badano, J.M., Quiroga, M. E., L'Argentiere, P.C., Coloma-Pascual, F. (2010). Influence of $\mathrm{Ni}$ Addition to a LowLoaded Palladium Catalysts on the Selective Hydrogenation of 1-Heptyne. Quimica Nova, 33(4): 18-28.

[23] Uddin, M., Wan Daud, W., Abbas, H. (2014). Co-production of hydrogen and carbon nanofibers from methane decomposition over zeolite Y supported Ni catalysts. Energy Conversion and Management, 90: 218-229.

[24] Al-Hassani, A., Abbas, H., Wan Daud, W. (2014). Production of COx-free hydrogen by thermal decomposition of methane over activated carbon: Catalyst deactivation. International Journal of Hydrogen Energy, 39(27): 14783-14791.

Selected and Revised Papers from The International Conference on Fluids and Chemical Engineering (FluidsChE 2015) (http://fluidsche.ump.edu.my/index.php/en/) (Malaysia, 25-27 November 2015) after Peer-reviewed by Scientific Committee of FluidsChE 2015 and Reviewers of BCREC 